\title{
HUBUNGAN ANTARA PRESTASI BELAJAR DAN TINGKAT KECEMASAN MATEMATIKA PADA MAHASISWA CALON GURU SD/MI
}

\author{
Ifada Novikasari \\ IAIN Purwokerto \\ email: ifa_da@yahoo.com
}

\begin{abstract}
:
Mathematics anxiety has been recognized as a feeling depressed and anxious when it deals with the manipulation of numbers and mathematical problem solving in the real life and the academic situations. The anxiety tend to occur in someone with low mathematical ability. That is, individuals with low mathematics anxiety more comfort to solve the problem than someone who has high anxiety. It is interesting to examine, because it will be proved whether there is a relationship between learning achievement and mathematics anxiety.
\end{abstract}

Keywords: learning achievement, mathematics anxiety

\section{PENDAHULUAN}

Berdasarkan UU No.14/2005 tentang guru dan dosen yaitu Kompetensi yang harus dimiliki guru adalah kompetensi pedagogik, professional, kepribadian, dan sosial. Kompetensi pedagogik yang dikuasai guru diantaranya pemahaman terhadap peserta didik serta kemampuan mengelola proses pembelajaran. Kemampuan Profesional merupakan penguasaan guru terhadap materi pembelajaran secara luas dan mendalam terkait dengan pelaksanaan tugas utamanya mengajar. kompetensi kepribadian guru adalah kemampuan kepribadian yang mantap, stabil, dewasa, arif, dan berwibawa, menjadi teladan bagi peserta didik dan berakhlak mulia. Kompetensi sosial yaitu merupakan kemampuan pendidik sebagai bagian dari masyarakat untuk berkomunikasi lisan dan tulisan, menggunakan teknologi komunikasi dan informasi secara fungsional, bergaul secara efektif dengan peserta didik, sesama pendidik, tenaga kependidikan, orangtua / wali peserta didik, dan, bergaul secara santun dengan masyarakat sekitar. Sehingga guru disebut berkompeten apabila mampu menyeimbangkan dan meningkatkan keempat kompetensi di atas sehingga kinerjanya sesuai dengan standar yang telah ditetapkan secara nasional maupun internasional.

Kompetensi yang diharapkan dimiliki oleh seorang guru menjadi pertimbangan di dalam perkuliahan program persiapan guru SD/MI. Salah satunya membekali mahasiswa calon guru dengan penguasaan matematika karena matematika merupakan salah satu mata pelajaran wajib yang diajarkan di SD/MI. Kompetensi ini terkait bekal kompetensi profesional seorang guru dengan memperhatikan sistem pendidikan serta kurikulum pendidikan yang telah diikuti mahasiswa sejak pendidikan dasar sampai perguruan tinggi. Sebagaimana menurut Baumslag (2000:3) penting bagi dosen di perguruan tinggi saat mengajarkan matematika memperhatikan konsep matematika yang telah dipelajari oleh mahasiswa pada jenjang sebelumnya. Artinya meskipun materi matematika di LPTK merupakan materi yang diberikan di SD/MI namun perkuliahan yang 
diberikan memperhatikan sisi bagaimana menguasai konsep dan mengajarkan matematika di SD/MI.

Penguasaan calon guru terhadap matematika selama ini dinilai oleh pendidik guru atau dosen melalui tugas atau tes. Terkait kemampuan penyelesaian tugas mahasiswa, menurut studi yang dilakukan oleh Sheffield dan Hunt (2007) kecemasan matematika memiliki pengaruh langsung pada kemampuan menyelesaikan tugas siswa.

Berdasarkan penelitian yang dilakukan oleh Novikasari (2013) di dua LPTK menunjukkan hasil bahwa mahasiswa LPTK A memiliki kemampuan operasi logis Piaget yang lebih baik dengan tingkat kecemasan yang tidak jauh berbeda dengan mahasiswa LPTK B. Hal ini tentunya memerlukan penelitian yang lebih lanjut mengenai hubungan prestasi mahasiswa dalam mata kuliah matematika dengan kecemasan yang dimiliki. Seberapa besar tingkat kecemasan mahasiswa terhadap mata kuliah matematika. Hal ini juga dapat digunakan untuk menilai sejauh mana ketertarikan mahasiswa dalam mengikuti perkuliahan matematika.

Berdasarkan observasi yang dilakukan oleh peneliti selama mengajarkan mata kuliah rumpun matematika, terkadang ditemukan tidak ada hubungan keaktifan mahasiswa untuk mengemukakan pendapat di kelas dengan prestasi belajarnya. Keaktifan di kelas dapat dikaitkan dengan keberanian menyampaikan ide atau tidak merasa cemas untuk menyampaikan gagasan terkait permasalah matematika. Hal ini mendorong peneliti untuk mengukur sejauh mana kasus tingkat kecemasan mahasiswa selama mengikuti perkuliahan matematika berpengaruh terhadap prestasi belajar matematikanya. Kecemasan matematika menurut (Sheffield \& Hunt, 2007) merupakan perasaan cemas seseorang yang dialaminya ketika dihadapkan pada masalah matematika. Perasaan tertekan ini terkait dengan manipulasi bilangan dan pemecahan masalah matematika. Dikaitkan dengan mata kuliah rumpun matematika di LPTK akan menjadi penelitian yang menarik dikaji mengenai hubungan antara tingkat kecemasan dan prestasi belajar matematika mahasiswa calon guru SD/MI.

Permasalahan dalam penelitian ini adalah apakah terdapat pengaruh tingkat kecemasan terhadap prestasi belajar matematika mahasiswa calon guru SD/MI yang telah mengikuti mata kuliah matematika?

Istilah prestasi itu sendiri berasal dari bahasa belanda yaitu prestasie. Dalam Kamus Besar Bahasa Indonesia (1989:700), prestasi belajar adalah penguasaan pengetahuan atau keterampilan yang dikembangkan oleh mata pelajaran, lazimnya ditunjukkan dengan nilai tes atau angka yang diberikan oleh guru. Menurut Buchori (1983: 94) mendefinisikan prestasi belajar adalah hasil belajar yang dicapai atau ditunjukkan oleh siswa sebagai hasil belajar baik angka atau huruf serta tindakannya yang mencerminkan hasil belajar yang dicapai masing-masing dalam periode tertentu. Angka atau hasil belajar itulah yang menunjukkan hasil belajar.

Jadi, pengertian prestasi belajar adalah tingkat kemampuan intelektual yang dapat diukur, berupa penugasan, pengetahuan, sikap dan keterampilan sebagai hasil belajar. Prestasi belajar dalam penelitian ini merupakan nilai akhir yang diperoleh mahasiswa selama mengikuti perkuliahan matematika. Nilai akhir tersebut merupakan akumulasi dari keaktivan 20\%, penugasan 20\%, dan hasil ujian mahasiswa $60 \%$. Selama proses 
perkuliahan dosen menilai keaktifan mahasiswa dari kemampuan mahasiswa menjelaskan konsep dan menyelesaikan masalah matematika di kelas. Perkuliahan matematika tersebut bertujuan mengembangkan keterampilan dalam mengajarkan matematika melalui proses, penanaman konsep dasar, pemahaman konsep, dan pembinaan keterampilan.

Mata kuliah matematika dalam program pendidikan guru SD/MI memberikan bekal kemampuan mahasiswa untuk menguasai materi matematika yang nantinya akan diajarkan di pendidikan SD/MI. Untuk mencapai tujuan tersebut selain melalui ekspositori dan diskusi, mahasiswa diberikan tugas secara kelompok dan individu untuk mempelajari teori-teori yang berhubungan dengan pembelajaran matematika SD/MI.

Prestasi belajar diduga memiliki keterkaitan dengan kecemasan matematika. Kajian kecemasan matematika diawali dengan observasi pada guru matematika pada awal 1950an. Pada tahun 1957, Dreger dan Aiken mengenalkan kecemasan matematika sebagai istilah baru untuk menggambarkan sikap siswa yang kesulitan matematika. Mereka mendefinisikannya sebagai "the presence of a syndrome of emotional reactions to arithmetic and mathematics" (Baloglu \& Zelhart, 2007). Kecemasan matematika didefinisikan oleh Ashcraft (2002) sebagai perasaan tertekan dan takut ketika dihadapkan dengan kemampuan matematika.

Menurut Tobias (dalam Furner \& DeHass, 2011) kecemasan matematika merupakan perasaan tertekan dan cemas ketika berkaitan dengan manipulasi angka dan pemecahan masalah matematika dalam situasi kehidupan nyata dan akademik.
Beberapa siswa cenderung lebih cemas pada proses tes dan seringkali ketakutan (kecemasan tes matematika), dan yang lain takut mengambil kelas matematika, hal ini dapat terjadi di sekolah dasar, sekolah menengah, sekolah tinggi atau tingkat kampus (kecemasan pelajaran matematika). Tobias merasa bahwa kecemasan dapat menyebabkan lupa dan hilangnya rasa percaya diri. Hal ini diperkuat pendapat Ashcraft (2002) tingginya kecemasan matematika seseorang ditandai kecenderungan untuk menghindari matematika. Meskipun penyebab kecemasan matematika belum ditentukan, hal ini dapat dikaitkan sebagai faktor resiko dari beberapa gaya mengajar.

Kecemasan matematika cenderung terjadi pada sesorang dengan kemampuan matematika kurang. Artinya, individu dengan kecemasan matematika tinggi memiliki keterampilan atau latihan yang lebih sedikit dengan individu yang memiliki kecemasan matematika rendah. Individu dengan kecemasan matematika cenderung menjauhi kelas matematika dan belajar sedikit matematika dalam pelajaran yang mereka ambil. Pengaruh sosial dan kemampuan kognitif siswa cenderung menjadi sebab kecemasan matematika di sekolah. Pengaruh sosial siswa berasal dari guru yang cemas tentang kemampuan matematika dirinya sehingga memberi sikap negatif pada beberapa siswa mereka. Sedangkan pengaruh kemampuan kognitif disebabkan oleh keterampilan dasar yang lemah, misalnya lemah dalam menghitung atau memahami bangun ruang akan menyebabkan berkembangnya kecemasan matematika (Maloney \& Beilock, 2012).

Instrumen dalam penelitian menggunakan instrumen kecemasan matematika yang telah dikembangkan oleh Freedman (2014). Instrumen 
tersebut digunakan untuk mengukur perasaan cemas mahasiswa terhadap matematika, tes matematika dan perkuliahan matematika.

Ciri kecemasan matematika dalam diri seseorang diantaranya sebagai berikut (Freedman, 2014):

1. Adanya rasa takut terhadap matematika;

2. Adanya anggapan bahwa matematika itu menyulitkan (selalu berprasangka negatif);

3. Adanya rasa tegang saat belajar matematika;

4. Adanya rasa takut tidak bisa mengerjakan soal matematika;

5. Adanya rasa takut dan malu tidak bisa menjawab pertanyaan guru saat belajar matematika;

6. Adanya rasa tidak percaya diri belajar matematika;

7. Sering lupa terhadap konsep matematika.

\section{METODE PENELITIAN}

Penelitian ini menggunakan metode penelitian kuantitatif dengan pemilihan sampel secara acak mahasiswa program studi PGMI yang telah mengikuti mata kuliah rumpun matematika IAIN Purwokerto. Sebagai metode, difokuskan pada pengumpulan, analisis, dan menggunakan data kuantitatif dalam uji korelasi.

\section{HASIL PENELITIAN DAN PEMBAHASAN}

Sesuai dengan tujuan penelitian tersebut di atas, maka sajian hasil penelitian ini meliputi paparan prestasi belajar dan kecemasan matematika matematika pada mahasiswa calon guru SD/MI

\section{Prestasi Belajar Matematika}

Data prestasi belajar matematika diperoleh dari hasil nilai akhir perkuliahan mahasiswa dalam Matematika I dan Matematika II. Perkuliahan Matematika I membahas tentang Bilangan dan Aritmatika, dan perkuliahan Matematika II tentang Geometri. Tabel 1 berikut ini menyajikan perbandingan rata-rata dan standar deviasi nilai akhir perkuliahan Matematika I dan Matematika II mahasiswa PGMI.

Tabel 1 Hasil Belajar Matematika

\begin{tabular}{|l|c|c|}
\hline \multicolumn{1}{|c|}{ Prestasi } & Matematika I & Matematika II \\
\hline Rata-rata & 67 & 57,87 \\
\hline Standar Deviasi & 10,85 & 14,72 \\
\hline
\end{tabular}

Hasil belajar dalam mata kuliah Matematika I dan Matematika II di atas menunjukkan bahwa rata-rata Matematika I lebih tinggi dibandingkan Matematika II. Standar deviasi yang diperoleh menunjukkan bahwa sebaran nilai Matematika I lebih homogen dibandingkan dengan nilai Matematika II. Hal ini menunjukkan bahwa nilai Matematika I memiliki nilai rata-rata yang lebih tinggi serta memiliki kecenderungan nilai mahasiswa yang seragam. Hal ini dapat diartikan bahwa nilai Matematika I lebih baik daripada nilai Matematika II mahasiswa. Kurva perolehan nilai pada mata kuliah Matematika I dan Matematika II tersebut dapat digambarkan seperti pada Gambar 1. 
e-ISSN 2442-5419 Vol. 5, No. 2 (2016) 120-127

p-ISSN 2089-8703

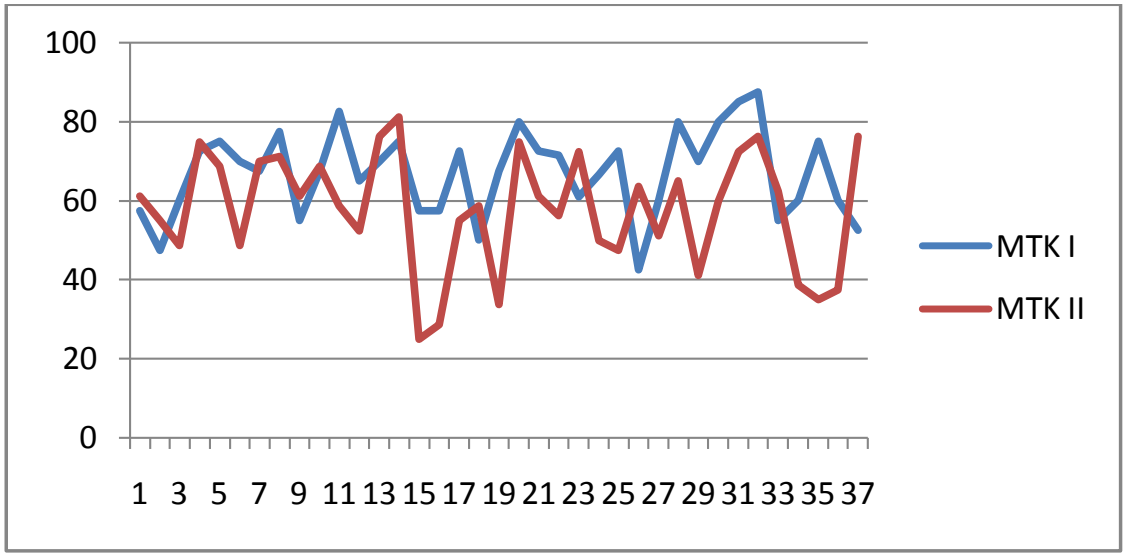

Gambar 1 Grafik Nilai Matematika I dan Matematika 2 pada 37 Mahasiswa.

Perolehan nilai dalam mata kuliah Matematika I dan Matematika II dalam penelitian ini selanjutnya digabungkan untuk dibandingkan dengan kecemasan matematika mahasiswa. Tabel 2 berikut ini mendeskripsikan skor total gabungan hasil belajar dalam mata kuliah Matematika I dan Matematika II pada mahasiswa calon guru SD/MI.

Tabel 2 Statistik Deskriptif Gabungan Mata Kuliah Matematika I dan Matematika II

\begin{tabular}{|l|r|r|r|r|r|r|}
\hline & \multicolumn{1}{|c|}{$\mathrm{N}$} & Minimum & Maximum & Sum & Mean & $\begin{array}{c}\text { Std. } \\
\text { Deviation }\end{array}$ \\
\hline HslBeljr & 37 & 41.25 & 81.88 & 2310.23 & 62.4386 & 10.31661 \\
Valid N Listwise) & 37 & & & & & \\
\hline
\end{tabular}

Tabel 2 menunjukkan bahwa hasil belajar gabungan nilai pada mata kuliah Matematika I dan Matematika II diperoleh nilai tertinggi 81,88 dan nilai terendah 41,25 dengan rata-rata nilai 62,44 .

\section{Kecemasan Matematika}

Berdasarkan data yang diperoleh pada 37 mahasiswa yang diteliti akan dikelompokkan mahasiswa kelompok atas, sedang, dan kurang menggunakan data berupa rata-rata $(\bar{X})$ dan standar deviasi (s). Statistik deskriptif yang menggunakan SPSS 17 diperoleh hasil sebagai berikut:

Tabel 3 Statistik Deskriptif Kecemasan Matematika

\begin{tabular}{|l|r|r|r|r|r|r|}
\hline & N & Minimum & Maximum & Sum & Mean & $\begin{array}{c}\text { Std. } \\
\text { Deviation }\end{array}$ \\
\hline TkKecemasan & 37 & 2 & 30 & 687 & 18.57 & 6.327 \\
Valid N \\
(listwise)
\end{tabular}

Nilai rata-rata pada tes kecemasan matematika adalah 18,57 dan standar deviasi diperoleh nilai 6,327. Karena penilaian pada jawaban angket dikaitkan dengan angka atau nilai bagi suatu pernyataan yang mendukung sikap negatif, $\mathrm{SS}=1, \mathrm{~S}=2, \mathrm{~N}=3, \mathrm{TS}=$ 4 , dan $\mathrm{STS}=5$ maka nilai tertinggi 
menunjukkan kecemasan matematika yang rendah. Kelompok atas dengan kecemasan matematika rendah apabila mahasiswa mendapatkan nilai di atas $18,57+6,327=24,897$, kelompok sedang jika total tes kecemasan matematika berada di antara 24,897 dan
18,57-6,327 = 12,243. Kelompok mahasiswa dengan kecemasan tinggi jika mahasiswa mendapatkan nilai di bawah 12,243. Berikut ini deskripsi sebaran kelompok kecemasan matematika mahasiswa.

Tabel 4 Sebaran Tingkat Kecemasan Matematika

\begin{tabular}{|lr|c|c|}
\hline \multicolumn{2}{|c|}{ Tingkat Kecemasan Matematika } & Rentang nilai & $\begin{array}{c}\text { Jumlah } \\
\text { Mahasiswa }\end{array}$ \\
\hline $\begin{array}{l}\text { Kelompok } \\
\text { rendah) }\end{array}$ & Atas $\quad$ (Tk.Kecemasan & Nilai $\geq 24,897$ & 9 \\
\hline $\begin{array}{l}\text { Kelompok } \\
\text { sedang) }\end{array}$ & Sedang $\quad$ (Tk.Kecemasan & $12,243 \leq$ Nilai $<24,897$ & 24 \\
\hline $\begin{array}{l}\text { Kelompok } \\
\text { tinggi) }\end{array}$ & rendah $\quad$ (Tk. Kecemasan & Nilai < 12,243 & 4 \\
\hline
\end{tabular}

Pembagian kelompok mahasiswa berdasarkan Tabel 4 di atas menunjukkan bahwa jumlah terbesar mahasiswa calon guru SD/MI memiliki tingkat kecemasan sedang dalam mengikuti perkuliahan dan menghadapi ujian matematika.

\section{Hubungan Prestasi Belajar Matematika dan Kecemasan Matematika dalam Pembelajaran Matematika}

Analisis data untuk mengetahui hubungan antara prestasi belajar matematika dan kecemasan matematika dilakukan dengan menggunakan SPSS 17 dengan menggunakan korelasi Spearman dan hipotesisnya adalah:

$\mathrm{H}_{\mathrm{o}}$ : Tidak ada hubungan (korelasi) antara dua variabel

$\mathrm{H}_{\mathrm{i}}$ : Ada hubungan (korelas) antara dua variabel

Tabel 5 Korelasi Prestasi Belajar Matematika dan Kecemasan Matematika

\begin{tabular}{|rl|r|r|}
\hline & & Prestasi Belajar & TkKecemasan \\
\hline Spearman's rho Prestasi & Correlation & 1.000 & -.268 \\
Belajar & Coefficient & & \\
& Sig. (2-tailed) &. & .109 \\
& $\mathrm{~N}$ & 37 & 37 \\
\cline { 2 - 4 } & Tk.Kecemasan Correlation & -.268 & 1.000 \\
& Coefficient & .109 & \\
& Sig. (2-tailed) & 37 & 37 \\
& $\mathrm{~N}$ & &. \\
& & & \\
& & &
\end{tabular}


Hasil korelasi Spearman pada tabel 5 menunjukkan bahwa korelasi prestasi belajar matematika dan kecemasan matematika mahasiswa calon guru menunjukkan nilai -0,268 dengan signifikansi 0,109 . Korelasi tersebut dapat diartikan bahwa hubungan antara prestasi belajar matematika dan kecemasan matematika memiliki hubungan negatif yang tidak signifikan, semakin tinggi prestasi belajar matematika maka semakin rendah nilai jawaban angket kecemasan matematika atau semakin tinggi prestasi belajar matematika maka semakin tinggi kecemasan matematika mahasiswa.

Berdasarkan hasil analisis statistik menunjukkan bahwa prestasi belajar matematika memiliki hubungan negatif yang lemah dengan kecemasan matematika mahasiswa dalam mengikuti perkuliahan dan ujian matematika. Hubungan antara prestasi belajar matematika dan kecemasan matematika memiliki hubungan negatif, semakin tinggi prestasi belajar matematika maka semakin rendah nilai jawaban angket kecemasan matematika atau dapat diartikan semakin tinggi prestasi belajar matematika maka semakin tinggi kecemasan matematika mahasiswa. Sebanyak 24 orang mahasiswa menunjukkan jumlah terbesar berada pada kelompok sedang dalam hal kecemasan matematika. Temuan tersebut juga didukung oleh temuan Ramirez dkk (2016) bahwa besarnya kecemasan matematika seseorang dalam memecahkan masalah matematika akan mendukung keberhasilan matematika seseorang. Sebab, perasaan cemas menyebabkan seseorang maksimal dalam menyelesaikan masalah matematika.

Mahasiswa dengan prestasi belajar rendah memiliki kecenderungan kecemasan matematika yang rendah. Penelitian ini menunjukkan hampir tidak ada hubungan antara prestasi belajar matematika dengan kecemasan matematika karena lemahnya hubungan tersebut. Analisis selama proses perkuliahan diperoleh informasi bahwa mahasiswa dengan prestasi belajar kurang menunjukkan kecenderungan memiliki kecemasan matematika yang rendah dan sedang. Mahasiswa tidak merasa cemas atau tertekan dalam mengikuti perkuliahan dan menghadapi ujian matematika. Hal ini dapat disebabkan selama perkuliahan mahasiswa tidak memahami materi. Dalam pembelajarannya, menunjukkan Dosen menggunakan berbagai pendekatan dalam menyampaikan materi. Namun apabila dilihat dari pencapaian prestasi belajar mahasiswa, mahasiswa masih memiliki kekurangan dalam pemecahan masalah matematika sebab Quiz, tugas, dan ujian yang diberikan dosen menekankan pada penerapan matematika dalam memecahkan masalah. Sebagaimana kajian Ramirez dkk (2016) seseorang dengan kecemasan tinggi akan mencoba menggunakan berbagai strategi dalam pemecahan masalah sehingga dapat diperoleh hasil yang diinginkan.

Hubungan yang lemah antara prestasi belajar dan kecemasan matematika ini menunjukkan bahwa pada mahasiswa calon guru SD/MI yang diteliti tersebar antara mahasiswa yang memiliki kecemasan matematika sedang dan rendah dengan prestasi belajar yang rendah.

\section{KESIMPULAN DAN SARAN}

Penelitian untuk menyelidiki hubungan antara prestasi belajar matematika dan kecemasan matematika pada mahasiswa calon guru SD/MI ini menunjukkan hasil terdapat hubungan antara prestasi belajar matematika dengan kecemasan matematika. Prestasi belajar matematika mahasiswa 
dipengaruhi oleh kecemasan matematika dengan korelasi sebesar 0,268 memiliki hubungan negatif yang lemah. Semakin tinggi prestasi belajar matematika maka semakin tinggi pula kecemasan matematika yang dimiliki sebagai usaha untuk menyelesaikan masalah matematika yang dihadapi.

Penelitian yang akan datang perlu dilakukan dengan mengkaji penyebab kecemasan yang dimiliki oleh mahasiswa calon guru SD/MI. Lemahnya hubungan prestasi belajar mahasiswa terhadap kecemasan matematika dimungkinkan diketemukannya variabel lain penyebab peningkatan kecemasan matematika mahasiswa.

\section{DAFTAR PUSTAKA}

Ashcraft, Mark H. 2002. Math Anxiety: Personal, Educational, and Cognitive Consequences. American Psychological Society, Volume 11, Number 5.

Baloglu, M. \& Zelhart, P. 2007. Psychometric properties of the revised mathematics anxiety rating scale. The Psychological Record, 57, hlm. 593-611.

Baumslag, B. 2000. Fundamentals of teaching Mathematics at University Level. London: Imperial College Press.

Buchori. 1983. Evaluasi dalam Pendidikan. Bandung: Jemars.

Depdikbud, 1989. Kamus Besar Bahasa Indonesia. Jakarta: Balai Pustaka.

Freedman, E. 2014. Do You Have Math Anxiety?

A Self Test. www.mathpower.com diakses 10 Desember 2014
Furner \& DeHass. 2011. How do Students' Mastery and Performance Goals Relate to Math Kecemasan? Eurasia Journal of Mathematics, Science \& Technology Education. www.ejmste.com diakses 11 Desember 2012.

Maloney \& Beilock. 2012. Math Kecemasan: Who has it, Why it Develops, and How to Guard Against It. Trends in Cognitive Science Vol.16 No. 8. http://hpl.uchicago.edu/ Publications/TiCS\%20Final_Malo ney\&Beilock_2012.pdf diakses 10 Desember 2014.

Novikasari, I. 2013. Perbandingan Kemampuan Penalaran Analogis, Kreativitas Matematika dan Anxiety Matematika pada Mahasiswa Calon Guru MI ditinjau dari Kurikulum Rumpun Matematika dan Pembelajarannya di PTAIN. Penelitian di IAIN Purwokerto: Tidak Dipublikasikan.

Ramirez, Chang, Maloney, Levine, \& Beilock. 2016. On the relationship between math anxiety and math achievement in early elementary school: The role of problem solving strategies. Journal of Experimental Child Psychology, 141, hlm. 83-100.

Sheffield, D., Hunt, T. 2007. How Does Kecemasan Influence Maths Performance and What Can We About It? MSOR Connections, Vol.6 No.4 November 2006Januari 2007. mathstore.ac.uk/headocs/ 6419_kecemasanmaths.pdf. diakses 11 Desember 2012. 